\begin{tabular}{ll}
\hline & $\begin{array}{l}\text { Kastamonu Eğitim Dergisi } \\
\text { Kastamonu Education Journal }\end{array}$ \\
$\begin{array}{l}\text { Eylül 2019 Cilt:27 Sayı:5 } \\
\text { kefdergi.kastamonu.edu.tr }\end{array}$ & Başuru Tarihi/Received: 02.09 .2018 \\
& Kabul Tarihi/Accepted: 28.11 .2018 \\
Dol: $10.24106 /$ kefdergi.3319
\end{tabular}

\title{
Harmanlanmış Bir Kültürde Yaşamak: Adana'da Göçmen Çocuklar
} Living in a Blended Culture: Immigrant Children in Adana

\section{Öz}

\author{
Zekiye ÇAĞIMLAR ${ }^{1}$, Metin ALTUNKAYNAK ${ }^{2}$
}

Bu araştırmanın amacı, Suriyeli göçmen ilkokul öğrencilerinin ürettikleri mecazlar üzerinden yaşadıkları kültürel uyum problemlerinin belirlenmesidir. Veriler Adana'da ilkokul öğrenimi gören 8'i kız 6'sı erkek olmak üzere toplamda 14 öğrenciden görüşme yoluyla toplanmıştr. Nitel araştırma olarak tasarlanan bu çalışmada veriler mecazlar yoluyla veri toplama yöntemiyle elde edilmiş ve olgubilim modeli kullanılmıştr. Suriyeli göçmen ilkokul öğrencilerinin kültürün öğeleri olan dil, inanç, gelenek ve görenek, sanat, dünya görüşü ve tarih açısından yaşadıkları uyum problemleri ile ilgili düşünceleri temalar çerçevesinde hazırlanan sorularla tespit edilmeye çalışılmıştr. Verilerin analizinde betimsel analiz yöntemi kullanılmıştr. Öğrenciler tarafindan 6 temaya ilişkin geçerli 46 mecaz geliştirilmiştir. Geçerlik ve güvenirliliği sağlamak için ise iki farklı uzmanın her birine elde edilen veri setinin yarısı verilmiş ve yaptıkları incelemeler sonucunda Miles ve Huberman (2016) tarafindan önerilen formül kullanılmıştır. Araştırmanın sonuçlarına göre kültürel uyumun öğelerinden; dil ile ilgili 9, inanç ile ilgili 7, gelenek ve göreneklere ilişkin 9, sanata ilişkin 9, dünya görüşüne ilişkin 5, tarihe ilişkin 6 mecaz geliştirilmiş ve her tema ayrı ayrı değerlendirilmiştir. Araşttrmanın son bölümünde öğretmenlere, velilere, eğitim kurumlarına ve öğrencilere çeşitli önerilerde bulunulmuştur.

Anahtar Kelimeler: betimsel analiz, göçmen ilkokul öğrencileri, kültürel uyum, mecazlar, öğrenci görüşleri.

\section{Abstract}

The aim of this study is to determine cultural adaptation problems of Syrian immigrant primary school students through the metaphors they generate. Data were gathered through interviews from 14 students ( 8 female, 6 male) who are primary school students in Adana. In this study, which is designed as a qualitative research, data were obtained by data collection through metaphors method and phenomenology model was used. Thoughts of Syrian immigrant primary school students' adaptation problems in terms of language, belief, tradition, art, world perspective and history, which are the elements of culture, were tried to be revealed through the questions prepared around these themes. Descriptive analysis method was used to analyze data. 46 valid metaphors were generated by students in reference to 6 themes. To ensure the validity and reliability, half the data sets obtained from the research were sent to each expert and at the end of the analysis they made, the formula proposed by Miles ve Huberman (2016) was used. According to the results, out of cultural adaptation elements; 9 metaphors for language, 7 metaphors for belief, 9 metaphors for traditions, 9 metaphors for art, 5 metaphors for world perspective and 6 metaphors for history were generated and each theme was assessed seperately. In the final part of the research, several suggestions were made to teachers, parents, education institutions and students.

Keywords: cultural adaptation, descriptive analysis, immigrant primary school students, metaphors, student interviews

1 Çukurova Üniversitesi, Eğitim Fakültesi, Temel Eğitim Bölümü, Adana, Türkiye; https://orcid.org/0000-0002-2022-0014

2 Çukurova Üniversitesi, Sosyal Bilimler Enstitüsü, Adana, Türkiye; https://orcid.org/0000-0001-6947-7526

Atıf / Citation: Çağımlar, Z. \& Altunkaynak, M. (2019). Harmanlanmış bir kültürde yaşamak: Adana'da göçmen çocuklar .Kastamonu Education Journal, 27(5), 20892102. doi:10.24106/kefdergi.3319 


\section{Extended Abstract}

Purpose: The aim of this research is to determine the cultural adaptation problems of migrated Syrian refugee primary school students through the metaphors they have generated. Six research questions were prepared in order to determine whether these perceptions reflect the definition, content, level and general characteristics of cultural harmony.

Method: In this study, which is designed as a qualitative research, data were obtained by data collection through metaphors method and phenomenology model was used. Sensing the nature and the environment; metaphors allow an individual to 'knowing' as a means of giving meaning to life and experience, inferring from the objective realities which seem to be meaningless, making sense through specific interpretations (Yildırım and Şimşek, 2016).

The participants of the research consists of 14 students who were determined by purposeful sampling and who were actively educated at the 2017-2018 academic year of the second semester in the province of Yüreğir in Adana. After a comprehensive review of the issue by the researchers (Tufan, 1987; Sung, 2008; Erden, 2017), questions were formed that could reveal cultural adaptation problems of Syrian migrant children and a semi-structured interview form was prepared by consulting expert opinions.

The research investigated the adaptation problems of the migrated Syrian refugee primary school students who are educated in Turkey, in terms of language, religion, traditions and customs, art, worldview, and history which are elements of their culture. In the analysis of the data, descriptive analysis method was used. 46 available metaphors under 6 themes were developed by the students. In order to provide validity and reliability, each of the two specialists was given half of the data set obtained and as a result of their examination, the formula proposed by Miles and Huberman (2016) was used.

Results and Discussion: According to the results of the research; of the elements of cultural harmony; 9 related to the language; 7 related to faith and beliefs, 9 related to traditions and customs, 9 related to Art, 5 related to worldview, 6 metaphor related to history were developed and each theme was evaluated separately. All of the metaphors they developed about Turkish made positive associations. It is seen that Syrian migrant children use the most school metaphor (28.6\%) and two students use teacher and peace metaphor (14.4\%). Apart from these metaphors, one student $(7,1 \%)$ expressed house, friend, market, television, song and game metaphors.

Of all the elements of the culture, when the metaphors related to the faith and beliefs were examined, all but one of the students who participated in the research expressed positive metaphors. The student who expressed the metaphor about begging expressed that his family sometimes made him beg in the traffic lights and told him to use religious expressions for the people he asked for money. Four students expressed the metaphor heaven $(28,6 \%)$, three students solidarity $(21,3 \%)$, two students fast breaking and charity $(14,4 \%)$.

Other metaphors expressed by Syrian students: to beg, Hz. Muhammad and prayer (7,1\%). Most of the Syrian migrant children 's neighbourhood metaphor regarding the Turkish traditions and customs, were repeated by $21.3 \%$. The metaphor for the seeing off the soldiers to the army and joining the festivals was expressed equally (14.4\%). Other metaphors which the students mentioned are feasts and meals, circumcision ceremonies, patient visits, visiting newborn babies, respect for the elders and hospitality (8,3\%).

Syrian migrant children expressed a negative and eight positive metaphors about Turkish artworks. Mostly song metaphor (21.3\%) was repeated. Story and essay metaphors were expressed by two students for each $(14,4 \%)$. Other positive metaphors expressed are; flowers, entertainment, communication, teachers and big clock tower $(8,3 \%)$. The negative expression is boring $(8,3 \%)$ metaphor. The theme for the Turkish values and judgments has been the least mentioned metaphor compared to other themes. The metaphor homeland for this theme was repeated most frequently (28.6\%). The metaphors about flag and love were expressed by three students for each (21.3\%). Family and heroic metaphors were expressed in (14.4\%). The last theme mostly expressed on the cultural items regarding Turkish history was the sibling metaphor (21.3\%) by the Syrian migrant children. The metaphors Atatürk and grandfather were expressed by two students for each (14.4\%) War, TV series and time metaphors can be rated as (8,3\%).

This research, which aims to reveal the perceptions of selected participants by means of data gathering through metaphor for the determination of the cultural adaptations experienced by the Syrian migrant primary school students, collected the opinions of students about the language, beliefs, traditions and customs, arts, worldviews and history themes, which are cultural items, and the following conclusions are reached;

Migrants to our country due to the civil war in Syria have started to learn Turkish through various institutions in Turkey and have developed various perceptions of the Turkish language. It will be possible for the migrant children in school age to be successful in their school life and their adaptation to the society they live in if they are able to learn the mother tongue of Turkish society. The results for the beliefs; having the same beliefs and the same religious groups in Syria and Turkey has led to positive opinions except one point on this theme.

The most expressed metaphor by the students about tradition and customs is the neighborhood. Neighborhood relationships have developed so much in our society that neighbours are regarded as family members. The most frequently expressed metaphor about Turkish artworks by the Syrian migrant children is the songs. It can be inferred that the songs they hear and learn in school and they watch on television facilitate their Turkish learning.

When metaphorical developments of Syrian migrant children about the worldview (Turkish values and judgments) are taken into consideration, the metaphor of homeland takes the first place on the forefront. The last theme of the cultural items is the Turkish history. When we examine the metaphors generated, it is understood that the students develop the concepts metaphorically that we use frequently or have an important place in life.

In the last part of the research; various suggestions were made to the teachers, parents, educational institutions and the students.

| Kastamonu Eğitim Dergisi, 27(5), 2019| 


\section{Giriş}

Siyasal ve ekonomik nedenlere bağlı olarak dünyada birçok gelişme yaşanmaktadır. Bu gelişmeler ülkeler, toplumlar ve bireyler üzerinde önemli etkiler bırakmıştr. Bunun doğal bir sonucu olarak kültürler arası yakınlaşma, çok kültürlülük, çok dillilik, uluslararası uyumlar gibi kavramlar sıkça tartşılmaya başlanmıştı. Bu kavramlar arasında çok kültürlülük, göçmenlerin kültürel ihtiyaçları bağlamında ortaya çıkmıştır. Çok kültürlülüğün bu kadar yoğun tartışımasında en önemli nedenlerinden birisi yaşanan göçlerdir. Tarih boyunca insanlar farklı nedenlerden dolayı yaşadıkları yerlerden göç etmişlerdir. İnsanların bir kısmı daha iyi yaşam koşullarına sahip olmak için göç etmekteyken, bir kısmı da doğal afet, terör, savaş vb. nedenlerden dolayı başka ülkelere zorunlu olarak göç etmek durumunda kalmışlardır. Suriye'deki iç savaş böyle bir zorunluluğu meydana getirmiştir. Arap ülkelerinde 2010 yılında başlayan iç karışıklıklar Suriye'ye de sıçramış, zamanla savaş ve şiddet ortamı yaklaşık 7 milyon insanı ülkelerinden göç etmek zorunda bırakmıştr. Türkiye'nin "açık kapı" yaklaşımının da etkisiyle 3 milyondan fazla Suriyeli Türkiye'ye gelmiştir (AFAD, 2017). Suriye'deki savaşın bitmemesi ve geldikleri yerlerdeki evlerin yıkılmış olması nedeniyle, göçmenlerin ülkelerine yakın bir zamanda geri dönmeyeceği düşünülmektedir (Emin, 2016). Uzun süre ülkemizde ikamet edecek Suriyeli göçmenlerin yarısından fazlası eğitim çağındadır (AFAD, 2017). Göçmenlerin beslenme, giyinme, güvenlik, ikamet gibi temel ihtiyaçlarının yanı sıra okula gitmeme sorunu da öne çıkmaktadır (Emin, 2016). Zorunlu olarak göçün beraberinde getirdiği sorunlar içinde göçmen çocukların okullaşması, temel ihtiyaçlar arasında sayılmalıdır. Okullar, çocukların yalnız eğitim öğrenim gördükleri mekânlar değil, bireylerin sosyalleştikleri, bütünleştikleri yerlerdir (Sakı, 2016). Temel insan hakları arasında yer alan eğitimin, göçmen veya vatandaş olanlar ayrımı yapılmadan, ülkede yaşayan bütün çocuklar için verilmesi gerekir (European Commission Against Racism and Intolerance, 2011). Göçmen çocukların tamamının okula erişimleri sağlandığı takdirde göçün getirdiği olumsuzlukların aşılması kolaylaşacağı düşünülmektedir.

Türkiye kendi imkânlarıyla göçmenlerin başta eğitim olmak üzere birçok intiyacını karşıladığı gibi başta Avrupa Birliği $(A B)$ olmak üzere birçok ülkeden de destek almaktadır. AB'nin Türkiye'deki «Geçici Koruma Kapsamındaki Suriyeliler" in sağlık, insani yardım, psikolojik destek ve eğitim gibi alanlarda hibeler yoluyla bütçelenen "Suriyeli Çocukların Türk Eğitim Sistemine Entegrasyonunun Desteklenmesi" projesi 03.10.2016 tarihi ile yürürlüğe girmiştir. Türkiye'ye sığınan ya da başka bir ülkeye göç etmek üzere Türkiye'de ikamet izni talep eden münferit yabancılar ile topluca sığınma amacıyla sınırlarımıza gelen yabancılara ve olabilecek nüfus hareketlerine uygulanacak usul ve esaslar hakkındaki yönetmeliğin 27. maddesinin (2015) "Göçmen ve sığınmacıların ülkemizde kalacakları süre ile sınırlı olarak öğrenim görmeleri ve çaıışmaları genel hükümlere bağlıdır" hükmünce göçmen çocukların öğrenim görmeleri sağlanmaktadır. Bunun için Milli Eğitim Bakanlı̆̆ı (MEB) farklı düzenlemelerle tedbirler alarak çocukların okullara gitmelerini sağlamaya çalışmaktadır.

İç savaştan önce, Suriye okullaşma anlamında çevresindeki ülkelerden ileri durumdaydı. Birleşmiş Milletler raporuna göre; yetişkin okuryazar oranı 2005 yılında \%80, bu oran genç nüfusta \%92,5, temel eğitimden faydalanma oranı kız ve erkek gruplarının her ikisi için de \%95'idi. Ancak yaşanan iç karışıklıklar nedeniyle, Suriye'deki eğitim faaliyetleri durma noktasına gelmiştir. 2017 yılı itibariyle Suriye'de okul çağındaki 4,8 milyon çocuğun yarısı okula gidememektedir (Erden, 2017). Suriyeli göçmenlerin büyük bir kısmı kadın ve çocuklardan oluşmaktadır. Çocukların öğrenim hakkından faydalanması, yaşadıkları topluma uyumlarının sağlanması, suça bulaşmalarının engellenmesi ve ileride nitelikli işlerde çalışmaları hem ülkemiz için hem de gerekli şartlar oluşturulup ülkelerine döndüklerinde, ülkelerini yeniden yapılandırabilmeleri için önem arz etmektedir (Akkaya, 2013).

Taylor ve Sidhu (2012), göçmen çocukların sığındığı ülkelere aidiyet duygularının gelişimi ve göç ettikleri ülkenin kültürüne uyum sağlamada okulların çok önemli rol oynadığını belirtmektedir. Suriyeli ve ev sahibi topluluklar arasındaki kültürel ve sosyal farklılıklar, eğitim otoritelerini bu çocukların devlet okullarına yerleştirilmesi için neler yapılması gerektiğini sorgulamalarına neden olmuştur (Erden, 2017). Bu çocukların okul sistemindeki ihtiyaçlarına cevap vermek için alınan tedbirlerden biri de göçmen nüfusun çok olduğu yerlerde daha fazla öğretmen atanmasıdır (Türkeş, 2013). Türk hükümeti AFAD (Afet ve Acil Durum Yönetimi Başkanlığı) aracılığıyla Suriyeli öğretmenlerin kamp okullarında öğretmenlik yapmalarına izin vermektedir (AFAD 2017; Türkeş, 2013). Kamp dışındaki Suriyeli göçmen çocuklar, Türk çocuklarla birlikte aynı okullarda eğitim görmektedir.

2013 yılında Save the Children, göçmen çocuklar için kamplarda ve kentsel alanlarda yaptığı araşttrmalarda, birçok göçmen çocuğun kaliteli eğitim için sınırlı erişime sahip olduğunu ya da dil engeli gibi nedenlerle devlet okullarına gitmekte zorluk çektiğini belirlemiştir. Ancak Türkiye'deki göçmen Suriyeli çocukların eğitime erişim sorununun çözümü amacıyla, Milli Eğitim Bakanlı̆̆ (MEB) tarafindan Yabancılar ve Uluslararası Koruma Kanunu kapsamında yayımlanan 2014/21 sayılı "Yabancılara Yönelik Eğitim-Öğretim Hizmetleri Genelgesi" ile bu sorun ciddi oranda aşıldığını değerlendirmektedir. Devletin aldığı tedbirlerin yanı sıra kültürel uyum problemlerinin çözülmesi ile de Suriyeli göçmen çocukların okula erişimlerinin önündeki engellerin aşılacağı düşünülmektedir. Birlikte eğitim gören Suriyeli ve göçmen 
çocukların, ancak bir kültürel uyum içinde olduklarında başta eğitim olmak üzere birçok sorunun ortadan kalkacağı bilinmelidir (Erden, 2017).

Araştırmamızda Suriyeli göçmen çocukların kültürel uyum problemleri incelenmiştir. Uyum ve kültürün tanımları şu şekildedir. Uyum, bireyin, çevresel koşullara ya da değerlere ruhsal bakımdan kendini uydurması süreci (TDK, 2018), bireyin kendisiyle yaşadığı çevre arasında dengeli bir ilişki kurup ve bu ilişkiyi devam ettirebilmesidir. Kültür, tarihsel, toplumsal gelişme süreci içinde yaratılan bütün maddi ve manevi değerler ile bunları yaratmada, sonraki nesillere iletmede kullanılan, insanın doğal ve toplumsal çevresine egemenliğinin ölçüsünü gösteren araçların bütünü (TDK, 2018) olarak tanımlanmıştır. Konuşulan dilden, inanca, gelenek ve görenekten sanata, dünya görüşünden tarihe kadar her alanda kültür etkisini gösterir. Kültür, antropolog Edward B. Tylor (1871) tarafindan yapılmıştır. Kültür, bireyin yaşadığı toplumdan elde ettiği dil, inanç, gelenek ve görenek, sanat, dünya görüşü (değer ve yargılar) ve tarihten oluşan karmaşık bir bütündür (Akt. Sung, 2008). Araştırmamızın temalarını oluşturan kültürün bu öğeleri aşağıda açıklanmıştır.

Kültürün en önemli öğesi dildir denilebilir. Kültürü yaşatan dildir, dil de kültür ile gelişir ve birikir (Günay, 1995). Bir topluma ait olan dil, o toplumdaki insanların genel kültürünü ortaya koyar. Kültür bir bilgi birikimi olup bu birikiminin kaynağı da dildir. Bundan dolayı dil ile kültür ayrılmayan iki parçadır (Aslan, 2008). Göçer (2012) kültür ve dil ilişkisini ifade ederken "şu halde kültür, nesilden nesile aktarılmak için dile muhtaç; toplumun duygu, düşünce ve tam anlamıyla hayat tezahürlerinin somut hâle bürünmesinin aracı olan dil için de kültür bir ihtiyaçtı" demektedir. Bir toplumda konuşulan dilin zenginliği aynı zamanda o kültürünün zenginliğidir. Dil etkin ve canlı bir yapıda olduğunda ortaya çıkan ürünler sayesinde kültürel zenginliğin etkisi ortaya konulabilir. Kültürel zenginlik dilin etkili kullanmada söz sahibine yardımcı olur. Sahip olunan değerler ile kültür, ifadeye güçlü kılar. Özetle; kültür, dil için çok önemli bir kaynak; dil de kültür için vazgeçilmez bir araçtır (Göçer, 2012).

Kültürün şekillenmesinde toplumsal koşullar etkin rol oynar. Ancak kültür sadece maddi yaşam koşullarının sonucu değildir. Kültürün önemli belirleyici öğelerinden biri de manevi unsur yani toplumun inancıdır (Erkan, 2016). Dolayısıyla din içinde bulunduğu toplumu etkiler, şekillendirir. Dini alandaki değişmeler kültürün diğer alanlarında da değişime neden olur (Turhan, 2002). Birçok toplumda din ile kültür arasında karşılıklı etkileşim vardır. Din ile kültür bir araya geldiğinde diğer bir ifadeyle din bir kültüre dâhil olduğunda, onu kendi değerlerine uygun bir biçimde dönüştürmek ve kendi kuralları doğrultusunda düzenleyip ve biçim vermek ister. Ancak her insan ve toplumun kendine has kültürel bir yapısı olduğu için dinin kültür ile karşılaşmasında insandan insana, toplumdan topluma farklılıklar doğmaktadır (Erkan, 2016). Din ile kültürün karşılıklı etkileşimleri, gündelik hayatta açık olarak görülebilmektedir. Bir yandan inanç, kültürü etkisine alıp dönüştürürken, öte yandan kültür de, bulunduğu toplumdan çıkan veya içinde karşılık bulan inancı değişik şekillerde etkiler (Okumuş, 2016).

Toplumlar, bireyleri bir arada tutan, destekleyen gelenek ve görenekler üzerine inşa edilmiştir. Gelenek ve göreneklerin sayesinde birlikte yaşayan insanlar birbirlerine karşı olumlu yaklaşmalar geliştirir, toplumda sosyalleşmeleri sağlanır. Kim ve Stevens (1987), yardımlaşma, dayanışma ve paylaşma gibi sosyal tutumlar, insanların yaşadıkları toplumla sosyal bağlar geliştirmesini ve bu bağların kuvvetli bir şekilde sürekliliğini kolaylaştırır demektedir (Akt. Uzmen ve Mağden, 2002). Bir toplumun gelenek ve görenekleri o toplumun yazılı kanunlarının hazırlanmasında etkilerini gösterir. Kanunlar, bireylerin toplum içerisindeki tutum ve davranışlarını düzenleyip denetler. Toplumlar bu düzeni yüzyıllar boyunca gelenek ve görenekler yoluyla korumuştur (Köse, Tetik ve Ercan, 2001). Bununla birlikte günümüzde yazılı anayasası olmayan ülkeler mevcuttur. Bu toplumlar düzenlerini hâlâ gelenek ve göreneklerle korumaktadırlar. Aslında insanların bütün tutum ve davranışlarını yazılı kanunlarla düzenlemek mümkün olmayabilir. Çünkü kanunlar hakları ve cezaları düzenlemektedir. Bunlarla birlikte insanlar yaşadıkları toplumlardaki bireylerle çeşitli ilişkiler içindedir. Örneğin saygı göstermek, özür dilemek, selamlaşmak, konuşmak, tarţ̧̧mak vb. Bu tutum ve davranışların nasıl düzenleneceğini kanunlar değil gelenek ve görenekler belirler (İnal, 2007).

Sanat, bir toplumu diğer toplumlardan ayıran, bir topluma özgü duygu ve zevkleri ortaya çıkaran bir alandır. Sanat, alan yazında belli bir uygarlığın veya topluluğun anlayış ve zevk ölçülerine uygun olarak yaratılmış anlatım şeklinde geçen terimdir (TDK, 2018). O toplumun güzel olanı yaratma ve keşfetme yöntemidir. İnsanların barınma, beslenme, güvenlik gibi temel ihtiyaçlarının yanı sıra sosyal ve ruhsal ihtiyaçlarını da karşılama ihtiyacı vardır. Bu ihtiyaçlarını karşılarken vakit geçirmek, hoşuna gidecek etkinlikleri yapmak, güzel olanı bulmak ve yeni eserler ortaya koymak ister. Bütün bunları neticesinde sanat eserleri ortaya çıkar (Tok ve Yıgın, 2014). Her toplumun sanat yönelimi farklı özellikler taşır. Söylenen şarkılar, ortaya çıkan eserler, şehirlerin hatta evlerin planlanması, renkler, zevk ve anlayışları farklı farkIıdır. Özetle sanat bir toplumun ortak zevklerinin ifadesidir. Kültürün öğesi olan sanat; edebiyat, şarkılar, heykel, resim, mimarı vb. gibi alt dallara ayrılır (Buyurgan ve Buyurgan, 2012). 
Kültürün bir diğer öğesi olan dünya görüşü, bir toplumu başka toplumlardan ayıran yaşam felsefesidir. Bir toplumun bireyleri ortak kültürün etkisiyle tutum ve davranış yönünden çeşitli benzer özellikler ortaya koyarlar. Sosyal ve toplumsal olaylar karşısında bireylerin bu benzer zihniyet, tutum ve davranışları o toplumun dünya görüşünü meydana getirir (Kalın, 2010). Bundan dolayı her toplumda değerler ve değer yargıları farklılık gösterir. Askere gitme, kahraman olma, sevgi, ahlaki değerler, namus, temizlik anlayışları, ölümler, mutluluklar gibi yaşamsal olaylar ve kavramları her toplumda farklı yaklaşımlarla karşılanır (Arslanoğlu, 2005).

Toplumu ve kültürü oluşturan öğelerden diğeri olan tarih, bir toplumun yüzyıllar içindeki gelişim ve görünüşüdür. Tarih insan akııın gelişimidir. Tarih masal olmaktan çıkıp gerçek insanların geçmişte gerçekleştirdikleri eylemler halini alacaktır (Özbek ve Kotaman, 2014). Tarih geçmişi anlatır, ancak bu geçmişi dünün ve bugünün insanlarını toplum içerisinde birbiriyle ilişkilendirerek geleceğe taşır. Toplumun bireyleri arasında ortak kültürel değerler geliştirir. Aynı toplumda yaşayan insanlar tarih sayesinde ortak değerlere sahip olduklarını fark ederler. Tarih bir toplumun hangi aşamalardan geçip nasıl ilerleyeceğini ortaya koyan kültür öğesi olarak, o toplumdaki insanların yaşamında çok önemli bir yere sahiptir (Tuna ve Budak, 2013).

Çalışmada, ana odak, öğrencilerin betimlediği mecazlar yoluyla veri toplamaların kültürel uyum kavramını ve özelliklerini yansıttı̆ını göstermektir. Çalışma boyunca, Suriyeli ilkokul öğrencilerinin ifadeleri kullanılmıştır. Bu bağlamda, Suriyeli göçmen çocukların arasında kültürel uyum probleminin olup olmadığına bakılmaktadır.

Bu çalışmanın amacı, Suriyeli göçmen çocukların yaşadıkları kültürel uyum problemlerinin belirlenmesi için seçilen katılımcıların mecazlar yoluyla veri toplama yöntemi ile algılarını ortaya çıkarmaktır. Bu algıların kültürel uyumun tanımı, kapsamı, düzeyi ve genel özelliklerini yansıtıp yansıtmadığını tespit etmek için aşağıdaki soruların cevapları aranmıştır:

1. Suriyeli göçmen ilkokul öğrencileri Türkçeye ilişkin algılarını hangi mecazlarla açıklamaktadır?

2. Suriyeli göçmen ilkokul öğrencileri İslam dinine ilişkin algılarını hangi mecazlarla açıklamaktadır?

3. Suriyeli göçmen ilkokul öğrencileri Türk gelenek ve göreneklerine ilişkin algılarını hangi mecazlarla açıklamaktadır?

4. Suriyeli göçmen ilkokul öğrencileri Türk sanat eserlerine ilişkin algılarını hangi mecazlarla açıklamaktadır?

5. Suriyeli göçmen ilkokul öğrencileri Türk milletinin değer ve yargılarına ilişkin algılarını hangi mecazlarla açıklamaktadır?

6. Suriyeli göçmen ilkokul öğrencileri Türk tarihine ilişkin algılarını hangi mecazlarla açıklamaktadır?

Gerçekleştirilen bu çalışmayla; Suriyeli göçmen ilkokul öğrencilerinin, kültürel uyum problemlerinin açığa çıkarılması ve öğrencilerin kültürel uyumuna yönelik olarak uyum problemlerinin hangi açılardan aşılabileceğinin göz önüne serilmesi beklenmektedir.

\section{Yöntem}

Bu çalışma; araştırma sorularının doğası gereği nitel araştırma yöntemlerinden olgubilim deseni ile yürütülmüştür. Olgubilim deseni farkında olduğumuz ancak derinlemesine ve ayrıntılı bir anlayışa sahip olmadığımız olgulara odaklanmaktadır (Yıldırım ve Şimşek, 2016). Bize tümüyle yabancı olmayan, aynı zamanda da tam anlamını kavrayamadığımız olguları araştırmayı amaçlayan çalışmalar için olgubilim uygun bir araştırma zemini oluşturur. Olgubilim çalışmalarında genellikle bir olguya ilişkin bireysel algıların ortaya çıkarılması ve yorumlanması amaçlanır (Yıldırım ve Şimşek, 2016). Bu doğrultuda öğrencilerin kültürel uyum problemlerinin belirlenmesine ilişkin algıları ortaya çıkarılarak yorumlanmıştır. Mecazlar, olayların oluşumu ve işleyişiyle ilgili olarak düşüncelerin yapılandırıldığı, yönlendirildiği ve kontrol edildiği en güçlü zihinsel araçlardan biridir (Saban, 2004). Bu çalışmada mecazların analizi, öğrencilerin, kültürün her bir öğesine ait sorulara göre, örneğin "Türk tarihi ...... benzer çünkü ......" şeklinde verilen cümleyi doldurmaları ile elde edilmiştir. Bu bölümde yapılan araştırmanın çalışma grubuna, veri toplama aracına, veri toplama süreci ve araştırmacının rolüne, verilerin analizine ve geçerlik güvenirliğe yönelik bilgilere yer verilmektedir.

\section{Çalışma Grubu}

Araştırmadaki kathlımcılar, amaçlı örneklem yöntemlerinden ölçüt örnekleme yoluyla belirlenen ve 2017-2018 öğretim yılı ikinci dönemi itibariyle Adana ili Yüreğir ilçesinde aktif olarak öğrenim gören 14 öğrenciden oluşmaktadır. Katılımcılardan üçü ikinci sınıf, altısı üçüncü sınıf öğrencisi olup, beş öğrenci de dördüncü sınıfta okumaktadır. Katılımcılara ilişkin bilgiler Tablo 1'de sunulmuştur. 
Tablo 1. Katılımcılara İlişkin Bilgiler

\begin{tabular}{cccccc}
\hline Kod & Rumuz & Yaş & Cinsiyet & Okuduğu Sınıf & $\begin{array}{c}\text { Kaç yıldır okula } \\
\text { gittiği? }\end{array}$ \\
\hline 1 & SGiÖ.1 & 8 & Kız & 2 & 2 \\
2 & SGiÖ.2 & 8 & Erkek & 2 & 2 \\
3 & SGiÖ.3 & 8 & Kız & 2 & 2 \\
4 & SGiÖ.4 & 9 & Erkek & 3 & 3 \\
5 & SGiÖ.5 & 9 & Erkek & 3 & 3 \\
6 & SGiÖ.6 & 9 & Erkek & 3 & 4 \\
7 & SGiÖ.7 & 9 & Kız & 3 & 3 \\
8 & SGiÖ.8 & 10 & Kız & 3 & 3 \\
9 & SGiÖ.9 & 9 & Kız & 3 & 4 \\
10 & SGiÖ.10 & 10 & Kız & 4 & 4 \\
11 & SGiÖ.11 & 10 & Kız & 4 & 4 \\
12 & SGiÖ.12 & 11 & Erkek & 4 & 4 \\
13 & SGiÖ.13 & 11 & Kız & 4 & 4 \\
14 & SGiÖ.14 & 10 & Kız & 4 & \\
\hline \multicolumn{2}{l}{ SGiÖ. Suriyeli Göçmen ilkokul Öğrencisi } & & & 3 \\
\hline
\end{tabular}

Tablo 1'de görüldüğü gibi, katılımcıların 8'i kız, 6'sı erkektir. Katlımcılardan birisi hariç diğerlerinin okula gitme süreleri ile okudukları sınıf aynıdır. Katılımcıların yaşları 8 ile 11 arasında değişmektedir. Öğrenciler aynı okulda eğitim görüp aynı mahallede oturmaktadır ve 3 tanesi kardeş öğrencilerdir. Araştırmanın etik olarak uygun olması için, katlımcılar araştırma hakkında bilgilendirilmiş, katılımcıların özel hayat dikkate alınarak kişisel bilgilerine yer verilmeyerek öğrencilere rumuzlar (SGiÖ) verilmiş ve katılımcıların araştırmaya gönüllü olarak katılması sağlanmıştr. Araştırmadan elde edilecek verilerin sadece bilimsel amaçla kullanılacağı ve katılımcıların zarar göreceği bir durumda kullanılmayacağı belirtilmiş ve katılımcılardan elde edilen veriler her hangi bir cümlesi değiştirilmeden kullanılmıştır. Katılımcıların belirlenmesinde amaçsal örnekleme yöntemlerinden ölçüt örnekleme yönteminden yararlanılmıştır. Bu örnekleme yönteminde, temel anlayış önceden belirlenmiş bir dizi ölçütü karşılayan bir örneklem grubuyla çalışmaktır (Yıldırım ve Şimşek, 2016). Katılımcı olarak seçilebilmek için; Suriyeli göçmen çocuklar olması, ilkokul öğrenimi görmesi, araştırmaya katılmaya istekli olması, okuma yazmayı bilmesi ve karne dönem sonu notları en az iyi düzeyde olması ölçütleri aranmıştır. Bu ölçütü karşılayan 20 Suriyeli öğrenciden, 14'ü gönüllü katılım göstererek araştırmanın çalışma grubunu oluşturmuştur.

\section{Kullanılan Veri toplama Aracı}

Bu çalışmada, veri toplamada, mecazlar yoluyla veri toplama yöntemiyle nitel araştırma yöntemi kullanılmıştır. Verilerin mecazlar amacıyla toplanmasının temel sebebi, öğrencilerin kültürel uyum kavramına yükledikleri anlamın ortaya çıkarılmasını sağlamaktır. Ayrıca mecazlar aracılığıyla hem daha kolay hem de katlımcılar için daha eğlenceli bir şekilde veriler elde edilebilir. Araştırmada katılımcıların kültürel uyum problemlerine yükledikleri anlamlar mecazlar aracılığıyla ortaya çıkarılmıştır. Bu amaçla katılımcılardan kültürün her bir öğesine ait sorulara göre, örneğin "Türk tarihi ...... benzer çünkü ....." cümlesini doldurmaları istenmiştir. Katılımcılara mecaz oluşturmaları için 10-20 dakika arası süre verilmiştir. Uygulamadan önce katılımcılara mecazın ne olduğu ve bu cümlelerin nasıl doldurulacağı sözel olarak açıklanmıştr. Katılımcıların kullanacakları mecazların her hangi canlı veya cansız nesne, kavram, olay veya olgu olabileceği açıkça vurgulanmıştır. Mecazlar, bireyin doğayı ve çevresini anlamasının, anlamsız gibi görünen nesnel gerçeklerin belirli yorumlar yoluyla anlamlar çıkarmasının, yaşant ve deneyime anlam kazandırmanın araçları olarak 'bilmeye' olanak sağlar (Yıldırım ve Şimşek, 2016). Mecazlar karmaşık değişkenlerin önemli özelliklerini basit bir formatta tanımlamakta oldukça etkilidirler, ancak bütün resmin yalnızca bir parçasını gösterir (Morgan, 1980; Sterman, 1985'den Akt. Yıldırım ve Şimşek, 2016). Bu bağlamda, araştırmacılar tarafindan kapsamlı bir alan yazın taraması yapıldıktan sonra (Tufan, 1987; Sung, 2008; Erden, 2017) Suriyeli göçmen çocukların kültürel uyum problemlerini ortaya çıkarabilecek sorular yazıımış ve en uygun olanlarıyla uzman görüşünden faydalanılarak yarı yapılandııılmış görüşme formu oluşturulmuştur. Çalışmada Türkiye'de eğitim gören Suriyeli göçmen ilkokul öğrencilerinin kültürün öğeleri olan dil, din, gelenek ve görenek, sanat, dünya görüşü ve tarih açısından yaşadıkları uyum problemlerini sorgulamaktadır. 


\section{Veri Toplama Süreci ve Araştırmacı Rolü}

Çalışmanın verileri 2018 yılının Haziran-Temmuz ayları arasında toplanmıştır. Veri toplama sürecinin başında, katılımcıların tamamı ile yüz yüze görüşmeler yapılmıştır. Çocukların eğitim gördükleri okullarda gerçekleştirilen yüz yüze görüşmeler 10-20 dakika sürmüştür. Görüşmeler esnasında öğrencilerin öğretmenleri hazır bulunmuştur. VeriIen yanıtlar ses kayıt cihazıyla kaydedilmiştir. Çalışmanın her aşamasında gönüllülük esası gözetilmiş ve öğrencilerin okullarından hem sözlü hem de yazılı olarak izinleri alınmıştır.

\section{Verilerin Analizi}

Araştırmada elde edilen verilerin çözümlenmesinde "betimsel analizi" tekniği kullanılmıştır. Bu yaklaşıma göre, elde edilen veriler, daha önceden belirlenen temalara göre özetlenir ve yorumlanır. Bu amaçla elde edilen veriler, önce sistematik ve açık bir biçimde betimlenir. Daha sonra yapılan bu betimlemeler açıklanır ve yorumlanır (Yıldırım ve Şimşek, 2016). Bu çalışmada Suriyeli ilkokul öğrencilerinin kültürel uyum algıları mecazlar yoluyla veri toplama yöntemi ile analiz edilmiştir. Anlatımı güçlü kılmak amacıyla faydalanılan söz sanatlarından biri de benzetmedir. Benzetme, bir şeyin niteliğini anlatmak için o niteliği eksiksiz taşıyan bir şeyi örnek olarak gösterme işi (TDK, 2018) olarak tanımlanır. Benzetmeler, mecazların ilk evresidir. Mecazlar, benzetmelerde amaçlandığı gibi, ifade edilmek istenilen ifadeye bir yönden benzerliği olan başka bir ifadeyle anlatılmaya çalışılır; böylece bir mecaz parçalarının toplamından daha büyük bir anlam yaratır ve bize yeni bir farkında olma sunar (Çelikten, 2005). Araştırmada katılımcı görüşleri doğrultusunda ulaşılan mecazlar; olumlu ve olumsuz olarak kodlanmışlardır. Tablo biçiminde mantıklı ve anlaşılır bir biçimde düzenlenen verilerden hareketle, ulaşılan sonuçlar yorumlanmaya çalışılmıştır. Katılımcı görüşlerini etkili bir biçimde ortaya koymak için doğrudan alıntılara bulgular bölümünde yer verilmiştir. Öğrenciler tarafından ifade edilen doğrudan alıntılarda anlatım bozuklukları araştırmacı tarafindan düzeltilerek araştırmaya eklenmiştir. Araştırmadan elde edilen kodlar ve kategoriler bu aşamada betimsel olarak (frekans (f), yüzde (\%)) sunulmuş elde edilen betimlemeler bu bölümde araştırmacı tarafindan yorumlanmış ve bu sonuçlara ilişkin olarak çözüm önerileri bu aşamada sunulmuştur (Yıldırım ve Şimşek, 2016). Bu bağlamda, bu çalışmada incelenen ana konu, kültürel uyum problemleri hakkındaki görüş ve deneyimlerine dayanarak katılımcıların tasvir ettiği mecazlar yoluyla veri toplanmasıdır.

\section{Geçerlik ve Güvenirlik}

Araştırmanın geçerliği için, araştırmacı tarafindan doğru ve kapsamlı bilgi alınması, araştırma rapor haline getirilirken katılımcılardan alıntıların yapııması ve alıntıların ekleme yapılmadan olduğu gibi verilmesi araştırmanın geçerliliğini artırıcı önlemler olarak görülebilir (Yıldırım ve Şimşek, 2016). Araştırmanın geçerliğini sağlamak üzere öncelikle iç geçerlik ve dış geçerliğe yönelik tedbirler alınmıştır. Bu araştırmada iç ve dış geçerliğini sağlamak için şu aşamalar uygulanmıştır: Araştırmanın örneklemi, araştırmanın yapıldığı mecazlar, veri toplama ve veri analiz süreci ayrıntılı olarak betimlenmiştir. İnandırıcılığı sağlamak için, araştırmanın özgünlüğü ve katılımcıların gizliliği ilkesine aykırı olmayacak şekilde katılımcılardan elde edilen mecazlar araştırmada birebir alınt olarak aktarılmıştır. Araştırmanın dil geçerliği için asıl uygulamaya geçilmeden önce rastgele seçilen dört katılımcıya pilot uygulama yapılmış ve katılımcıların anlamlandırmadıkları yerler ve karşılaşabilecekleri sorunlara yönelik ön çözümler sunulmuştur. Araştırmanın güvenirliğini sağlamak için iki farklı uzmanın her birine elde edilen veri setinin yarısı verilmiş ve yaptkkları incelemeler sonucunda Miles ve Huberman (2016) tarafindan önerilen formül (Güvenirlik: Görüş birliği/görüş ayrılığı+görüş birliği x100) uygulanmıştır. Nitel bir araştırma da güvenirliğin sağlanması için nitel çalışmalarda araştırmacı ile uzman arasındaki uyumun \%90 ve üzeri olmasının arzu edilebilir güvenirliği sağladığını belirtilmiştir (Saban, 2009). Öğrenciler tarafından 6 tema için toplam 47 mecaz geliştirilmiş ve uzmanlara karşılaştırmaları için verilmiştir. Karşılaştırma sonucunda araştırmacı ve uzmanlar 45 mecazda görüş birliği içinde, iki mecazda görüş ayrılığında olduğu görülmüştür. Bu hesaplama sonucunda ise yapılan analizin $[46 /(46+2)]=0,95$ oranında güvenirliğe sahip olduğu görülmüştür.

\section{Bulgular}

Suriyeli göçmen ilkokul öğrencilerinin kültürel uyum problemlerinin ortaya çıkarmak amacıyla kültürün öğeleri olan dil, din, gelenek ve görenek, sanat, dünya görüşü (Türk değer ve yargıları) ve tarih temaları belirlenmiş ve öğrencilerin kültürel uyuma ilişkin oluşturdukları mecazlar tablolar halinde sunulmuştur.

\section{Suriyeli Göçmen Illkokul Öğrencilerinin Türkçeye Iilişkin İfade Edilen Mecazlar}

Aşağıdaki tabloda Suriyeli göçmen çocuklar tarafindan geliştirilen mecazlar sıklık sırasına göre listelenerek her bir mecazı temsil eden öğrenci sayısı ve yüzdesi sunulmuştur. 
Tablo 2. Öğrencilerin Türkçeye ilişkin Geliştirdikleri Mecazlar ile Bunları İade Eden Öğrenci Sayısı ve Yüzdesi.

\begin{tabular}{rlcc}
\hline Kod & Mecazın Adı & $\mathrm{f}$ & $\%$ \\
\hline 1 & Okul & 4 & 28,6 \\
2 & Öğretmen & 2 & 14,4 \\
3 & Barış & 2 & 14,4 \\
4 & Ev & 1 & 7,1 \\
5 & Arkadaş & 1 & 7,1 \\
6 & Market & 1 & 7,1 \\
7 & Televizyon & 1 & 7,1 \\
8 & Şarkı & 1 & 7,1 \\
9 & Oyun & 1 & 7,1 \\
& Toplam & 14 & 100
\end{tabular}

Tablo 2'ye göre, 14 öğrencinin Türkçe ile ilgili mecazları incelendiğinde Suriyeli öğrencilerin kendilerini ifade etmekte zorlanmadıkları anlaşımaktadır. Türkçe ile ilgili geliştirdikleri mecazların tamamı olumlu çağrışımlar oluşturmaktadır. Suriyeli göçmen çocukların en fazla okul mecazını (\%28,6), iki öğrenci de öğretmen ve barış mecazlarını (\%14,4) kullandığı görülmektedir. Bu mecazlar dışında ev, arkadaş, market, televizyon, şarkı ve oyun mecazlarını $(\% 7,1)$ birer öğrenci ifade etmişlerdir.

Öğrenciler okul mecazını ifade ederken örnek olarak SGiÖ.2: "Türkçe okula benzer çünkü biz Türkçeyi okulda öğreniyoruz" şeklinde görüş belirtmiştir. Öğretmene ilişkin mecazı SGiÖ.3: "Türkçe öğretmene benzer çünkü bana Türkçeyi öğretmenim öğretti" şeklinde ifade etmiştir. Öğrencilerin geldikleri ülkede yaşanan savaşa karşın barış mecazını SGiÖ.6: "Türkçe barışa benzer çünkü burada savaş değil barış var, Türkçe öğrendik." şeklinde ifade etmiştir. Ev mecazını ifade eden öğrenci SGiÖ.8: "Türkçe eve benzer çünkü yeni evimiz Türkiye'de, dilleri Türkçe" şeklinde, arkadaş mecazını SGiÖ.11: "Türkçe arkadaşa benzer çünkü mahalledeki arkadaşlarım Türkçe biliyor" şeklinde, market mecazını SGiÖ.12: "Türkçe markete benzer çünkü her şeyin anlamını buluyorum" şeklinde, televizyon mecazını SGiÖ.13: "Türkçe televizyona benzer çünkü televizyonda Türkçe filim izliyorum." şeklinde, şarkı mecazını SGiÖ.14: "Türkçe şarkıya benzer çünkü Türkçe şarkılar hareketli, dans ediyoruz." şeklinde, oyun mecazını SGiÖ.7: "Türkçe oyuna benzer çünkü okulda oyun oynarken herkes Türkçe konuşuyor" şeklinde ifade etmişlerdir.

\section{Suriyeli Göçmen İlkokul Öğrencilerinin İnanca iliş̧kin İfade Edilen Mecazlar}

Araşttrmaya katılan çocukların kültürün bir öğesi olan inana ait geliştirilen mecazlar sıklık sırasına göre listelenerek her bir mecazı temsil eden öğrenci sayısı ve yüzdesi sunulmaktadır.

Tablo 3. Öğrencilerin İslamiyet'e ilişkin Geliştirdikleri Mecazlar ile Bunları Iffade Eden Öğrenci Sayısı ve Yüzdesi.

\begin{tabular}{clcc}
\hline Kod & Mecazın Adı & $f$ & $\%$ \\
\hline 1 & Cennet & 4 & 28,6 \\
2 & Yardımlaşma & 3 & 21,3 \\
3 & iftar & 2 & 14,4 \\
4 & Sadaka & 2 & 14,4 \\
5 & Dilenmek & 1 & 7,1 \\
6 & Hz. Muhammed & 1 & 7,1 \\
7 & Namaz & 1 & 7,1 \\
& Toplam & 14 & 100 \\
\hline
\end{tabular}

Kültürün öğelerinden inanca ilişkin mecazlar incelendiğinde, araştırmaya katılan öğrencilerin biri hariç tamamı olumlu mecazlar ifade etmişlerdir. Dilenmek ile ilgili mecazı ifade eden öğrenci ailesinin bazı zamanlarda trafik ışıklarında onu dilendirdiğini ve para istediği kişilere dini ifadeler kullanmasını söylediklerini ifade etmiştir. Dört öğrenci cennet 
(\%28,6), üç öğrenci yardımlaşma (\%21,3), iki öğrenci iftar ve sadaka (\% 14,4) mecazını ifade etmişlerdir. Suriyeli öğrenciler tarafindan ifade edilen diğer mecazlar ise; dilenmek, $\mathrm{Hz}$. Muhammed ve namaz $(\% 7,1)$ şeklindedir.

Öğrencilerin cennet mecazına ilişkin ifadelerine örnek olarak SGiÖ.1: "Islamiyet cennette benzer çünkü her istediğin duaya cevap veriliyor." şeklinde görüş belirtmiştir. Yardımlaşma mecazına ilişkin SGiö.4: "İslamiyet yardımlaşmaya benzer çünkü bizim paramız yoktu, komşular yardım etti." şeklinde görüş belirtmiştir. Iftar mecazına ilişkin SGiÖ.7: "islamiyet oruca benzer çünkü oruç olduğunda herkes bize iftar getiriyordu" şeklinde, sadaka mecazına ilişkin SGiÖ.9: "islamiyet sadaka almaya benzer çünkü paramız olmadığı zaman, Müslümanlar para veriyor" şeklinde, Hz. Muhammed mecazına ilişkim SGiö.4: "İslamiyet Hz. Muhammed'e benzer çünkü İslam peygamberi Hz. Muhammed'dir." şeklinde, namaz mecazına ilişkin SGiÖ.13: "Islamiyet namaza benzer çünkü en önemli şey namazdır" şeklinde görüş belirtmişlerdir. Olumsuz olarak belirtilecek mecaz olan dilenmek mecazı ile ilgili SGiö.12: "islamiyet dilenmeye benzer çünkü bizim gibi bir Suriyeli komşumuz ışıklarda dileniyor" şeklinde görüş belirtmiştir.

\section{Suriyeli Göçmen illkokul Öğrencilerinin Türk Gelenek Ve Göreneklerine ilişkin İade Edilen Mecazlar}

Araştırmaya katılan çocukların kültürün bir öğesi olan Türk gelenek ve göreneklerine ait geliştirilen mecazlar sıklık sırasına göre listelenerek her bir mecazı temsil eden öğrenci sayısı ve yüzdesi sunulmaktadır.

Tablo 4. Öğrencilerin Türk Gelenek ve Göreneklerine illişkin Geliştirdikleri Mecazlar ile Bunları ífade Eden Öğrenci Sayısı ve Yüzdesi.

\begin{tabular}{llll}
\hline Kod & Mecazın Adı & $\mathbf{f}$ & $\%$ \\
\hline 1 & Komşuluk & 3 & 21,3 \\
2 & Asker uğurlama & 2 & 14,4 \\
3 & Bayram gezmeleri & 2 & 14,4 \\
4 & Yemekler & 1 & 8,3 \\
5 & Sünnet düğünü & 1 & 8,3 \\
6 & Hasta ziyareti & 1 & 8,3 \\
7 & Çocuk görme & 1 & 8,3 \\
8 & Büyüklere saygı & 1 & 8,3 \\
9 & Misafirperverlik & 1 & 8,3 \\
& Toplam & 14 & 100 \\
\hline
\end{tabular}

Tablo 4'e göre Türk gelenek ve göreneklerine ilişkin Suriyeli göçmen çocukların en fazla komşuluk mecazı \%21,3 oranında tekrar edilmiştir. Asker uğurlama ve bayram gezmelerine ilişkin mecazlar eşit oranda $(\% 14,4)$ ifade edilmiştir. Öğrencilerin değindikleri diğer mecazlar ise yemekler, sünnet düğünü, hasta ziyareti, çocuk görme, büyüklere saygı ve misafirperverlik $(\% 8,3)$ mecazlarıdır.

Öğrencilerin komşuluk mecazına ilişkin örnek ifadeleri şu şekildedir. SGiö.1: "Türk gelenekleri komşuluğa benzer çünkü savaştan kaçanlara komşumuz Türkiye yardım etti" şeklindedir. Asker uğurlama mecazını SGiö.3: "Türk gelenekleri askere benzer çünkü askerlik burada çok çok önemliymiş" şeklinde, bayram gezmeleri mecazını SGiö.8: "Türk gelenekleri bayram gezmelerine benzer çünkü bayramda bütün komşuları ziyaret etmiştik" şeklinde ifade edilmiştir. Birer öğrenci tarafindan ifade edilen diğer mecazlardan olan yemekler mecazını SGiÖ.9: "Türk gelenekleri yemeğe benzer çünkü buradaki yemekleri çok seviyorum" şeklinde, sünnet dügünü mecazını SGiö.12: "Türk gelenekleri sünnete benzer çünkü Türk komşumuz Tarık sünnet olduğu için düğün yaptılar" şeklinde, hasta ziyareti mecazını SGiö.11: "Türk gelenekleri hasta ziyaretine benzer çünkü annem hastayken herkes bizim eve geldi" şeklinde, çocuk görme mecazını SGiÖ.13: "Türk gelenekleri bebek ziyaretine benzer çünkü buradakiler bebeği olan komşulara ziyarete gidiyor" şeklinde, büyüklere saygı mecazını SGiÖ.12: "Türk gelenekleri saygıya benzer çünkü Türkiye'de öğretmen ve büyüklere saygılılar" şeklinde, misafirperverlik mecazını SGiÖ.14: "Türk gelenekleri misafirliğe benzer çünkü arkadaşların evine oynamaya gittiğim zaman anneleri kızmıyor. Bazen ailecek gidiyoruz" şeklinde ifade etmiştir.

\section{Suriyeli Göçmen İlkokul Öğrencilerinin Türk Sanat Eserlerine İlişkin İfade Edilen Mecazlar}

Araştırmaya katılan çocukların kültürün bir öğesi olan Türk sanat eserlerine ait geliştirilen mecazlar sıklık sırasına göre listelenerek her bir mecazı temsil eden öğrenci sayısı ve yüzdesi sunulmuştur. 
Tablo 5. Öğrencilerin Türk Sanat Eserlerine ilişkin Geliştirdikleri Mecazlar ile Bunları Ifade Eden Öğrenci Sayısı ve Yüzdesi.

\begin{tabular}{clcc}
\hline Kod & Mecazın Adı & $\mathbf{f}$ & $\%$ \\
\hline 1 & Şarkı & 3 & 21,3 \\
2 & Hikâye & 2 & 14,4 \\
3 & Deneme & 2 & 14,4 \\
4 & Çiçek & 1 & 8,3 \\
5 & Eğlence & 1 & 8,3 \\
6 & Sıkıcı & 1 & 8,3 \\
7 & Iletişim & 1 & 8,3 \\
8 & Öğretmen & 1 & 8,3 \\
9 & Büyük saat & 1 & 8,3 \\
& Toplam & 14 & 100
\end{tabular}

Tablo 5'e göre Suriyeli göçmen çocuklar Türk sanat eserlerine ilişkin bir olumsuz sekiz olumlu mecaz ifade etmişlerdir. En çok şarkı mecazı (\% 21,3) tekrar edilmiştir. Hikâye ve deneme mecazları ikişer öğrenci tarafindan (\%14,4) ifade edilmiştir. İfade edilen diğer olumlu mecazlar ise; çiçek, eğlence, iletişim, öğretmen ve büyük saat $(\% 8,3)$ şeklindedir. Olumsuz olarak ifade edilen ise sıkıcı $(\% 8,3)$ mecazıdır.

Araştırmaya katılan öğrencilerin görüşmede en sık ifade ettikleri şarkı mecazını SGiÖ.2: "Türk sanat eserleri şarkıya benzer çünkü şarkılar gibi çok güzel" şeklinde örnek ifadeyle belirtmiştir. Hikâye mecazına örnek olarak SGiö.3: "Türk sanat eserleri hikayeye benzer çünkü hikaye okumak kadar eğlenceli" şeklinde, deneme mecazına ilişkin SGiö.5: "Türk sanat eserleri denemeye benzer çünkü çok farklı eserleri yapmayı deniyorum" ifadesini kullanmıştr. Birer öğrenci tarafindan ifade edilen mecazları açıklayan ifadelerden çiçek mecazına ilişkin SGiÖ.6: "Türk sanat eserleri çiçeğe benzer çünkü çiçek gibi rengârenk" şeklinde, eğlence mecazına ilişkin SGiÖ.9: "Türk sanat eserleri eğlenceye benzer çünkü okulda halk oyunları kursu var, çok eğlenceli" şeklinde, iletişim mecazına ilişkin SGiÖ.11: "Türk sanat eserleri iletişime benzer çünkü burada herkesle Türkçe iletişim kuruyorum" şeklinde, öğretmen mecazına ilişkin SGiö.12: "Türk sanat eserleri öğretmene benzer çünkü Türk sanat eserleri bu ülke hakkında bize bilgi veriyor" şeklinde, büyük saat mecazına ilişkin SGiö.13: "Türk sanat eserleri büyük saate benzer çünkü en güzel eser büyük saat, çok büyük ve güzel" şeklinde açıklamalar yapmışlardır. Olumsuz olarak değerlendirilebilecek sıkıcı mecazına ilişkin SGiÖ.10: "Türk sanat eserleri sıkıcı olmaya benzer Türkçe şarkıları anlamayınca sıkılıyorum" şeklinde görüş belirtmiştir.

Suriyeli Göçmen İlkokul Öğrencilerinin Türklerin Dünya Görüşüne (Türk Milletinin Değer Ve Yargılarına)illişkin ifade Edilen Mecazlar

Araştırmaya katılan çocukların kültürün bir öğesi olan Türk milletinin değer ve yargılarına ait geliştirilen mecazlar sıklık sırasına göre listelenerek her bir mecazı temsil eden öğrenci sayısı ve yüzdesi sunulmuştur.

Tablo 6. Öğrencilerin Türk Değer ve Yargılarına Ilişkin Geliştirdikleri Mecazlar ile Bunları İfade Eden Öğrenci Sayısı ve Yüzdesi.

\begin{tabular}{rlcc}
\hline Kod & Mecazın Adı & f & \% \\
\hline 1 & Vatan & 4 & 28,6 \\
2 & Bayrak & 3 & 21,3 \\
3 & Sevgi & 3 & 21,3 \\
4 & Aile & 2 & 14,4 \\
5 & Kahraman & 2 & 14,4 \\
& Toplam & 14 & 100 \\
\hline
\end{tabular}

Tablo 6'ya göre Türk değer ve yargılarına ilişkin tema diğer temalara göre en az mecaz oluşturulan tema olmuştur. Bu temaya ilişkin vatan mecazı en sık $(\% 28,6)$ tekrar edilmiştir. Bayrak ve sevgi mecazları üçer öğrenci tarafindan $(\% 21,3)$ dile getirilmiştir. Aile ve kahraman mecazları da \%14,4 oranında ifade edilmiştir.

Türk milletinin değer ve yargılarına ilişkin en sık ifade edilen vatan mecazına ilişkin öğrenci görüşüne örnek olarak SGiÖ.2: "Türklerin dünya görüşleri vatana benzer çünkü Türkler ülkelerini çok seviyorlar" ifadesini kullanmıştır. Bayrak mecazına örnek olarak SGiÖ.5: "Türklerin dünya görüşleri bayrağa benzer çünkü her yerde Türkler bayraklarını çıkarıyor" ifadesini, sevgi mecazına ilişkin SGiÖ.7: "Türklerin dünya görüşleri sevgiye benzer çünkü öğretmenimiz sürekli birbirinizi sevin diyor" ifadesini, aile 
mecazına ilişkin SGiÖ.8: “Türklerin dünya görüşleri aileye benzer çünkü Türkiye’de aile bağları çok güçü̈” ifadesini, kahraman mecazına ilişkin SGiÖ.11: “Türklerin dünya görüşleri kahramana benzer çünkü dizilerde büyük bir kahramanlar var" ifadesini kullanmıştr.

\section{Suriyeli Göçmen Illkokul Öğrencilerinin Türk Tarihine ilişkin Ifade Edilen Mecazlar}

Araştırmaya katılan çocukların kültürün bir öğesi olan Türk tarihine ait geliştirilen mecazlar sıklık sırasına göre listelenerek her bir mecazı temsil eden öğrenci sayısı ve yüzdesi sunulmaktadır.

Tablo 7. Öğrencilerin Türk Tarihine İlişkin Geliştirdikleri Mecazlar ile Bunları İfade Eden Öğrenci Sayısı ve Yüzdesi.

\begin{tabular}{clcc}
\hline Kod & Mecazın Adı & $\mathbf{f}$ & $\mathbf{\%}$ \\
\hline 1 & Kardeş & 3 & 21,3 \\
2 & Atatürk & 2 & 14,4 \\
3 & Dede & 2 & 14,4 \\
4 & Savaş & 1 & 8,3 \\
5 & TV dizisi & 1 & 8,3 \\
6 & Zaman & 1 & 8,3 \\
& Toplam & 14 & 100 \\
\hline
\end{tabular}

Tablo 7'de kültürün öğelerine ilişkin ifade edilen son tema olan Türk tarihine ilişkin Suriyeli göçmen çocukların en fazla dile getirdiği mecaz kardeş $(\% 21,3)$ olmuştur. Atatürk ve dede mecazı ikişer öğrenci tarafindan $(\% 14,4)$ ifade edilmiştir. Savaş, TV dizisi ve zaman mecazları $(\% 8,3)$ şeklinde sıralanabilir.

Türk tarihine ilişkin en sık ifade edilen kardeş mecazlara örnek olarak SGiÖ.1: "Türk tarihi kardeşe benzer çünkü bizi kardeşleri gibi görüyorlar" ifadesini, Atatürk mecazına ilişkin SGiÖ.4: "Türk tarihi Atatürk'e benzer çünkü öğretmenimiz sürekli onu öğretiyor" ifadesini, dede mecazına ilişkin SGiÖ.7: "Türk tarihi dedeye benzer çünkü tecrübeleri var" ifadesini, savaş mecazına ilişkin SGiö.10:" Türk tarihi savaşa benzer çünkü çok büyük savaşları kazanmışlar" ifadesini, televizyon dizisine ilişkin mecazı SGiÖ.11: "Türk tarihi televizyon dizisine benzer çünkü televizyonlarda tarihi dizi var" ifadesini, zaman mecazını SGiö.13: "Türk tarihi zamana benzer çünkü Türklerin çok eski bir tarihi var" ifadesini kullanmışlardır.

\section{Sonuçlar}

Suriyeli göçmen ilkokul öğrencilerinin yaşadıkları kültürel uyumlarının belirlenmesi için seçilen katılımcıların mecazlar yoluyla veri toplama yöntemi ile algılarını ortaya çıkarmayı amaçlayan bu araştırmada kültürün öğeleri olan dil, inanç, gelenek ve görenek, sanat, dünya görüşü ve tarih temalarına ilişkin öğrenci görüşleri toplanmış ve aşağıdaki sonuçlara ulaşılmıştir.

Suriye'deki iç savaş nedeniyle ülkemize gelen göçmenler Türkiye'de çeşitli kurumlar aracılığıyla Türkçe öğrenmeye başlamış ve Türkçeye ilişkin çeşitli algılar geliştirmişlerdir. Okul çağındaki göçmen çocukların, okul hayatında başarılı olmaları ve yaşadıkları topluma uyumlarının sağlanması Türk toplumunun ana dilini öğrenebilmeleriyle mümkün olabilecektir. Araştırmamıza katılan öğrencilerin Türkçe ile ilgili geliştirdikleri mecazların tamamı olumlu çağrışımlar oluşturmaktadır. Akkaya ve Karadağ çalışmalarında (2012) 5. sınıf öğrencilerinin genelde Türkçe, özelde ise Türkçe dersine ilişkin olumlu bir algıya sahip olduklarını tespit etmesiyle bu çalışmanın sonuçlarıyla örtüşmektedir. Öğrencilerin en sık ifade ettikleri mecazların okul ve öğretmen olması, onların Türkçeyi her yönüyle ve en yoğun şekilde okul ortamında ve öğretmenlerinden öğrendikleri sonucuna ulaşılabilir. Benzer şekilde Sakız (2016) araştırmasında olumlu bir okul kültürü içinde öğrencilerin Türkçeyi daha kolay öğrenip konuşabildikleri ifade etmiştir. Öğrencilerin ifade ettiği diğer mecazlar arasında yer alan barış ve ev mecazlarına ilişkin sonuçlar değerlendirildiğinde, savaştan kaçıp ülkemize sığınan göçmenlerin güvenli bir ortamda okula gittikleri ve okulda Türkçeyi kolay öğrenebildiği değerlendirilmiştir. Bu mecazlar MEB Suriyeli çocukların Türk eğitim sistemine entegrasyonunun desteklenmesi projesinin (2016) sonuçlarıyla da benzerlik göstermektedir. Araştırmada, Türkçeye ilişkin ifade edilen arkadaş ve oyun mecazları da çocukların mahalle ve okullarındaki Türk çocuklarla oynadıkları oyunların Türkçeyi öğrenmelerini kolaylaştırdığı sonucuna ulaşılabilir. Televizyon ve şarkı mecazları da izledikleri ve dinledikleri TV programları ve şarkılarının olumlu etkisi olduğu sonucuna ulaşılmıştır. Bir diğer mecaz olan market mecazı da alışveriş yaptıkları yerlerde Türkçe konuşulması ürünlerin Türkçe isimlerinin öğrenilmesine yardımcı olduğu sonucuna ulaşılmıştır.

Araştırmamızdaki kültürel uyumun bir diğer öğesi olan ikinci temamız, inanca ilişkin görüşleri ifade etmektedir. 
Suriye'de savaş öncesi başlıca dinî gruplar şu şekildedir: \%74 Sünni, \%12 Nusayri, \%10 Hıristiyan, \%3 Dürzî. Görüldüğü gibi Suriye halkının çoğunluğunu Sünni Müslümanlar teşkil etmektedirler (Akgün, 2012). Suriye ve Türkiye'de aynı dine ve dini gruba mensup olunmuş olması bu temaya ilişkin görüşlerin biri hariç olumlu olmasına neden olmuştur. Araştirmamızda din temasına ilişkin en sık tekrar edilen mecaz cennet olmuştur. Suriye'de yaşanan savaşta ölenlerin cennete gittiğine inanılması ve kendi yaşadıkları sıkıntların öldükten sonra bitip cennete gidecekleri düşüncelerinin bunda etkisi olabileceği düşünülmektedir. Yapılan araştırmalarda, öldükten sonra cennete gidileceği inancı İslam Dinin'de en yaygın beklentidir (Erkan, 2016). Göçmenlerin maddi birikimlerini ülkelerinde bırakıp gelmiş olmaları nedeniyle ekonomik olarak desteğe ihtiyaçları olduğundan yardımlaşma, iftar ve sadaka mecazları anlaşılır bulunmuştur. Türk halkının yardımsever olması göçmenlerin maddi sıkıntlları aşması ve kültürel uyumu daha kolay gerçekleştirebileceği sonucuna ulaşılabilir. Benze çalışmada Akdoğan (2012) yardımlaşma davranışının toplumlar arasındaki uyumu kolaylaştırdığı ve bağı güçlendirdiği sonucuna ulaşmıştir. Hz. SGiÖ.4 ve namaz mecazları da benzer şekilde iki farklı toplumun ortak inanç değerleridir. Bu temaya ilişkin olumsuz olarak ifade edilen dilenmek mecazı ise bazı göçmenlerin ekonomik yoksunluktan dolayı yapmak zorunda oldukları bir iş olarak gördükleri ancak birçok yönden her iki toplumun bireyleri arasında olumsuz sonuçlar ortaya çıkarmaktadır. Trafik ışıkları, cami önleri ve birçok yerde dilenen Suriyeli göçmen çocuklarla karşılaşılmaktadır. Benzer sonuca Akılı ve Dirikoç (2015) savaş travması yaşayan Suriyeli çocukların dilenerek ailelerinin geçimini üstlendiklerini için okula devam edemediklerini ayrıca psikolojik desteğe ihtiyaçlarının olduğunu, uyum sorunları yaşadıkları bildirilmiştir.

Araştırmamızın bir diğer teması olan gelenek ve göreneğe ilişkin öğrencilerin en çok ifade ettiği mecaz, komşuluktur. Toplumumuzda komşuluk ilişkileri o kadar çok gelişmiştir ki komşular aileden biri olarak görülmektedir. Akşit, Bozok ve Bozok (2015) tarafindan yapılan göçmenlerle komşuluk ilişkilerinin yürütüp yürütemedikleri ile ilgili yapılan araştırmada, Suriyelilerin onların yanında çalıştklarını ve böylece köye gelen Suriyeli aileyle komşuluk ilişkileri geliştirdiklerini söylediklerini ifade etmiştir. Askerlik, toplumumuzda çok değer verilen bir gelenek ve görenektir. Araştırmaya katılan çocuklar, komşuları arasında askere gidenlere düğün yapıldığı ve otogara kadar araç konvoyu yaparak uğurladıklarını ifade etmişlerdir. Türkler, çok geniş bir coğrafyaya yayılmışlar ve bu coğrafyayı hâkimiyet altına almışlardır. Bu hâkimiyetin kaynağı, Türklerin üstün askerlik yeteneğine bağlanmıştır. Türklerin askerliğe karşı tutumları, onların temel gelenek ve görenekleri arasında önemli bir yere sahiptir (Koçak, 2012). Askerlik gibi bayram gezmeleri de toplumumuzun önemli bir geleneğidir. Öğrenciler tarafindan ifade edilen diğer mecazlar yemekler, sünnet düğünü, hasta ziyareti, çocuk görme, büyüklere saygı ve misafirperverliktir. Misafirperverlik mecazı, komşuluk mecazı ile ilişkilendirilebilir. Birçok bilimsel araştırmada, bu sayılan mecazlar Türk toplumunun önemli gelenek ve görenekleri olduğu ifade edilmiştir (Çetin, 2008; Başal, 2006; Uca, 2004; Köse vd. 2001).

Kültürün bir öğesi olan Türk sanat eserlerine ilişkin Suriyeli göçmen çocukların en sık ifade ettiği mecaz, şarkılar olmuştur. Okulda duyup öğrendikleri ile televizyonda izledikleri şarkıların onların Türkçeyi öğrenmelerini kolaylaştrdığı sonucuna ulaşılabilir. Tok ve Yıgın (2014) tarafindan yapılan araştırmada da Suriyeli çocukların en çok Türkçe şarkılar dinlediklerini ifade edilmiş ve benzer sonuçlara ulaşılmıştır. Öğrencilerin bu tema ile ilgili ifade ettiği diğer mecaz hikâyelerdir. Çocukların ders kitaplarında yer alan ve öğretmenlerin okumaları için verdikleri hikâyelerden etkilendikleri söylenebilir. Benzer şekilde Aksan (1998) araştırmasında hikâye, roman ve diğer edebi ürünlerin ikinci dilin öğrenilmesini kolaylaştırdığı ve o dile ilişkin olumlu tutum kazandırdığını ifade etmiştir. Öğrencileri sınıfta ebru çalışması yaptıklarını ve bundan etkilendiklerini deneme ve çiçek mecazlarıyla ifade etmişlerdir. Ifade edilen diğer mecazlar eğlence, iletişim, öğretmen ve büyük saat mecazıdır. Adana ilinde bulunan tarihi büyük saat alanını görenlerin bundan etkilendikleri söylenebilir. Bunların yanı sıra öğrenciler olumsuz olarak değerlendirilecek sıkıcı mecazını da ifade etmişlerdir. Katılımcılar dinledikleri veya okudukları Türk sanat eserlerinden sıkıldıklarını dile getirmişlerdir. Özdemir (2017)'in yaptığı çalışmada da öğrencilerin nasıl yapılacağını anlayamadıkları faaliyetlerden sıkılacakları için seviyelerinin göz önünde bulundurulması sonucuna ulaşmıştır.

Suriyeli göçmen çocukların dünya görüşüne (Türk değer ve yargılarına) ilişkin geliştirdiği mecazlara bakıldığında, vatan mecazı öne çıkmaktadır. Bayrak ve sevgi mecazları üçer öğrenci tarafindan ifade edilmiştir. Aile ve kahraman mecazları ikişer öğrenci tarafindan dile getirilmiştir. Kahraman olarak dizilerde gördükleri kahramanlar etkili olmuştur. Arslanoğlu (2005), Türk değerlerini "Kahramanlık, yurtseverlik, mertlik, dindarlık, kanaatkârlık, tutumluluk, toprağa bağ|ıık, konukseverlik, saygı-hürmet, hayırseverlik, hoşgörülülük, namus-şereflilik, ciddilik ve ağırbaşlılık, alçakgönüllülük ve iç temizlik" olarak ifade etmiştir. Çalışmamızda da benzer sonuçlara ulaşımıştır.

Kültürün öğeleri arasında yer alan son tema da Türk tarihine ilişkindir. Oluşturulan mecazlar incelendiğinde sıkça kullandığımız veya hayatın içinde bizim için önemli yeri olan kavramların öğrenciler tarafindan mecaz olarak geliştirdikleri anlaşılmaktadır. En sık tekrar edilen tema kardeş temasıdır. Komşu iki ülkenin ortak bir tarihi olduğu düşünüldüğünde kardeş mecazı, iki ülkenin tarihsel gelişiminin birbirine bağlı olacağı değerlendirilebilir. Çetin ve Dinç (2017) yaptıkları 
çalışmada birbirine komşu iki ülkenin insanlarının benzer isimlere sahip oldukları için kardeş, arkadaş gibi mecazları ifade ettiklerini ortaya çıkarmışlardır. Atatürk ve dede mecazları ikişer öğrenci tarafindan dile getirilmiştir. Okulda ve ders kitaplarında Atatürk'ün kahramanlıkları ile ilgili konuların yer alması bu mecazların ifade edilmesinde etkili olduğu düşünülmektedir. Tuna ve Budak (2013) yaptıkları çalışmada Türk tarihine ilişkin Atatürk mecazının sık tekrar edildiği sonucunu ortaya çıkarmıştır. Savaş, televizyon dizisi ve zaman dile getirilen diğer mecazlardır.

\section{5. Öneriler}

Türkiye'de sayıları hızla artmakta olan göçmen çocuklarının eğitimi açısından kültürel uyum ile ilgili problemlerin çözümü için kültürün bütün öğeleri açısından gerekli adımların atılması gerekmektedir. Araştırmanın bulgularına dayalı olarak, Suriyeli öğrenciler için planlı bir eğitim ve kültürel uyum problemine çözümüne yönelik aşağıdaki öneriler getirilebilir.

Suriyeli öğrenciler, Türk toplumunun kültürüne ilişkin değerleri gözlemlediklerinde kendi kültürlerine ilişkin değerlerle benzerlik gösterdiğini fark edeceklerdir. Ortak kültürel değerler aracılığıyla Türk toplumunun kurallarını tanıyarak Türk toplumuna ait kültürel değerlere aykırı davranmamaları gerektiğini öğrenmeliler. Öğretmenlerin okumaları için verdikleri hikâye, roman vb. eserleri okumaları önerilmektedir.

Öğretmenlerine ilişkin öneriler ise sınıflarında bulunan her iki topluma ait çocukların kültürel farklılıkların getirdiği problemleri atlatmalarına yardımcı olmalıdır. Öğretmenler göçmen öğrencilerin anadillerinden birkaç kelimeyi öğrenebilirler. Kültürün bütün öğelerine ilişkin farkıııkları gidermek için gerekli etkinlikleri yapılmalıdır. Türk tarihine ilişkin filimler izletmek, tarihi mekânları gezdirmek örnek olarak verilebilir. Öğretmenler, öğrencilerin bireysel ve kültürel farklııklarına saygı duyuyorsa daha iyi uygulamalar ve önlemler mümkün olacağını bilmelidir. Ayrıca idareci ve öğretmenlere kapsayıcı eğitim verilmesi önerilmektedir.

Eğitim kurumları öğrenci, öğretmen ve veli arasında gerekli koordinasyonu sağlayarak ortak bir okul kültürü geliştirilmesi için okulda çeşitli aktivitelerin planlanarak haftalık, aylık, üç aylık, dönemlik ve yıllık kültürel etkinlikler düzenlenmesi faydalı olacaktır. Arapça dilini bilen psikolojik danışman ve rehber öğretmen bulundurulması, kültürel uyum problemlerinin aşılması başta olmak üzere birçok sorunun çözümüne katkısı olacaktır. Göçmen öğrencilerin eğitim gördüğü sınıflarda, öğrenci sayısının fazla olmamasına özen göstermeleri önerilmektedir

Türk öğrencilerin velileri ile Suriyeli göçmen çocukların velileri, çocukların birbirleriyle etkileşim içinde olmalarına ve oyunlar oynamalarına izin vererek kültürel uyum problemlerinin aşılmasına yardımcı olmaları önerilebilir.

\section{Kaynakça}

AFAD.(2017).Türkiye'deki Suriyelilerin demografik görünümü, yaşam koşulları ve gelecek beklentilerine yönelik saha araştırması. Ankara.

Akdoğan, A. (2012). "Kültür ve Din”, içinde: din sosyolojisi el kitabı, editörler: Niyazi Akyüz, İhsan Çapcıoğlu, Grafiker Yayınları, Ankara.

Akgün, B. (2012). Suriye krizinde bölgesel ve küresel aktörler (perspektifler, sorunlar ve çözüm önerileri), Sosyolojik Düşünce Enstitüsü Analiz. Ankara.

Akıllı, H, \& Dirikoç, A. (2015). Uydu kent Nevşehir'de göç çocukları, İdeal Kent Dergisi, Sayı 17, ss. 252-269

Akkaya, A, \& Karadağ, R. (2012). Türkçe dersine ilişkin ilköğretim 5. sınıf öğrencilerinin geliştirdikleri metaforlar. 11. Ulusal Sınıf Öğretmenliği Eğitimi Sempozyumu Bildiri Özetleri, Rize: Nobel Akademik Yayınclık.

Akkaya, A. (2013). Suriyeli mültecilerin Türkçe algıları [Syrian refugees' perceptions of Turkish language]. Ekev Akademi Dergisi, 17 (56), $179-190$.

Aksan, D. (1998). Dilbilim seçkisi: Günümüz dilbilimiyle ilgili yazılardan çeviriler, Türk Dil Kurumu, Ankara.

Akşit, G., Bozok, M., \& Bozok, N. (2015). Zorunlu göç, sorunlu karşılaşmalar: Hisar köyü, Nevşehir'deki Suriyeli göçmenler örneği. Maltepe Üniversitesi Fen-Edebiyat Fakültesi Dergisi, 1(2), 92-116.

Arslanoğlu, İbrahim (2005). Türk Değerleri Üzerine Bir Değerlendirme, Küreselleşme Karşısında Değerlerimiz Sempozyumu, Felsefe Dünyası Dergisi, 3-4 Haziran 2005/41, 64-77.

Aslan, Y. (2008). Yabancı dil eğitiminde dikkat edilmesi gereken noktalar. Türkiye'de yabancı dil eğitimi ulusal kongresi bildiriler. Gazi Ü. Gazi Eğitim Fakültesi, Editörler: S. Ağıldere ve N. Ceviz. 118-123. Ankara.

Başal, H. (2006). Türkiye'de doğum öncesi doğum ve doğum sonrası çocuk gelişimi ve eğitimine ilişkin gelenek, görenek ve inançlar. Uludağ Üniversitesi Eğitim Fakültesi Dergisi, 19(1), 45-70.

Buyurgan, S, \&Buyurgan, U. (2012). Sanat eğitimi ve öğretimi. Pegem Akademi. Ankara

Çelikten, M. (2005). Kültür ve öğretmen metaforları. Erciyes Üniversitesi Sosyal Bilimler Enstitüsü Dergisi, 21(2), $269-283$.

Çetin, C. (2017). Türk dügün gelenekleri ve kutsal evlilik ritüelleri. Ankara Üniversitesi Dil ve Tarih-Coğrafya Fakültesi Dergisi. $48(2), 111-126$.

| Kastamonu Eğitim Dergisi, 27(5), 2019| 
Çetin, Ş, \& Dinç, E. (2017). Ortaokul yedinci sınıf öğrencilerinin sosyal bilgiler algılarının incelenmesi. Diyalektolog Ulusal Sosyal Bilimler dergisi,16, 241-259.

Emin, M.N. (2016). Türkiye'deki Suriyeli çocukların eğitimi: Temel eğitim politikaları, SETA, sayı 53.

Erden, Ö. (2017). Schooling experience of syrian child refugees in Turkey, Doktora Tezi, Indiana University

Erkan, E. (2016). Suriyeli göçmenler ve dini hayat: uyum, karşılaşma, benzeşme Gaziantep örneği. illahiyat Akademi Dergisi (Gaziantep ilahiyat Fakültesi Dergisi), 3(4), 1-35.

European Commission against Racism and Intolerance. (2011). Irkçılık ve hoşgörüsüzlüğe karşı Avrupa komisyonu (ECRI) Türkiye raporu.<https://www.coe.int/t/dghl/monitoring/ecri/Country-by-country/Turkey/TUR-CBC-IV-2011-005-TUR.pdf> (2018, Temmuz 22)

Göçer, A. (2012). Dil-kültür ilişkisi ve etkileşimi üzerine. Türk Dili Dergisi, 729, 50-57.

Günay, D. (1995). Roman çözümlemesine toplum-dilbilimsel bir yaklaşım. Dil Dergisi, 35, 5-24.

Gaziantep Kent Konseyi (2014). Gaziantep'te Yaşan Suriyeli Misafirler ilişkin Rapor Sorunlar ve Çözüm Önerileri. 752,22.

Huberman, A.M.,\& Miles, M.B. (2016). Nitel Veri Analizi. Pegem akademi. Ankara.

İnal, K. (2007). Kente göç ve entegrasyon: Avrupa'daki göçmen Türk iterek yaşamında gelenek ve modernlik. Düşünce ve Araştırma Dergisi, 17, 85-100.

Kalın, İ. (2010). Dünya Görüşü, varlık tasavvuru ve düzen fikri: Medeniyet kavramına giriş. Divan Disiplinler Arası çalışmalar Dergisi, 15, 1-61 Koçak, K. (2012). Bozkır kültüründe alp karakterinin ortaya çıkışında Türk geleneklerinin etkisi. Neü Sosyal Bilimler Enstitüsü Dergisi, 1. $125-135$.

Köse, S., Tetik, S., \&Ercan, C. (2001). Örgüt kültürünü oluşturan faktörler. Yönetim ve Ekonomi Dergisi, 8(1), 219-242.

Levent, F. (2017). Türkiye'deki Suriyeli öğrencilerin eğitimine yönelik okul yöneticilerinin görüşleri. Hasan Ali Yücel Eğitim Fakültesi Dergisi,27, 21-46.

MEB. (2014). Yabancılara yönelik eğitim-öğretim hizmetleri. <http://mevzuat.meb.gov.tr/ html/yabyonegiogr_1/yabyonegiogr_1. html> (2018, Temmuz 24)

MEB. (2016). Suriyeli çocukların Türk eğitim sistemine entegrasyonunun desteklenmesi projesi, PICTES <https://pictes.meb.gov.tr/izleme>(2018, Temmuz 24)

Okumuş, E. (2016). Toplum bağlamında din-kültür etkileşimi, Turkish Studies Dergisi, ISSN: 1308-2140, Volume 11, $269-292$.

Özdemir, E. (2017). Suriyeli göçmenlerin Türkiye'deki algıları. Savunma Bilimleri Dergisi, 16, 135-136.

Özbek, Ö, \& Kotaman, H. (2014). Yeni bir eğitim yaklaşımı akılcı-istek kuramına giriş. Kastamonu Eğitim Dergisi, 22(1), $143-159$.

Saban, A. (2004). Giriş düzeyindeki sınıf öğretmeni adaylarının “öğretmen” kavramına ilişkin ileri sürdükleri metaforlar . Türk Eğitim Bilimleri Dergisi, 2(2), 131-155.

Saban, A. (2009). Öğretmen Adaylarının Öğrenci Kavramına İlişkin Sahip Oldukları Zihinsel İmgeler. Türk Eğitim Bilimleri Dergisi, 7(2), 281-326.

Sakız, H. (2016). Göçmen çocuklar ve okul kültürleri: Bir bütünleştirme önerisi. Göç Dergisi. 3(1), 65-81.

Save the Children (2013). Syria crisis: Education interrupted. UNICEF World Vision. <http://www.unicef.org/media/files/Education_Interrupted_Dec_2013.pdf> (2018, Temmuz 24)

Sung, D. (2008). University students' viewpoints toward incorporating English-speaking cultures into English learning. Proceedings of 2008 NUTN Conference on Innovative.

Taylor, S.,\& Sidhu, RK. (2012). Supporting refugee students in schools: What constitutes inclusive education? International Journal of Inclusive Education, 16(1), 39-56.

Tok, M, \& Yıgın, M. (2014). Türkçenin ikinci dil olarak öğretiminde öğrencilerin kullandıkları kelime öğrenme stratejileri.Dumlupınar Üniversitesi Sosyal Bilimler Dergisi, 41, 265-276.

Tufan, B. (1987). Türkiye’ye dönen ikinci kuşak göçmen işçi çocuklarının psiko-sosyal durumları. D.P.T. Sosyal Planlama Başkanlığı, Planlama Dairesi Yayınları, Ankara.

Tuna, Y. E, \& Budak, F. M. (2013). Sosyal bilgiler öğretmen adaylarının "tarih" kavramına ilişkin algılarının mecazlar/ metaforlar yardımıyla analizi. Adıyaman Üniversitesi Sosyal Bilimler Enstitüsü Dergisi, 6 (14), 609-642.

Tunç, A.Ş. (2015). Göçmen davranışı ve toplumsal etkileri: Türkiye'deki Suriyelilere ilişkin bir değerlendirme, TESAM Akademi Dergisi, 2(2), 29-63.

Turhan, M. (2002). Kültür Değişmeleri (Sosyal Psikoloji Bakımından Bir Tetkik), Çamlıca Yayınları, İstanbul.

Türk Dil Kurumu. (2018). Türk dil kurumu sözlüğü.<http://www.tdk.gov.tr/>(2018, Temmuz 21)

Türkeş, M (2013). Refugee problematics and Turkey, refugee and immigrant solidarity. Hope Association Magazine, 2(11), 5-6.

Uca, A. (2004). Türk toplumunda ad verme geleneği. Atatürk üniversitesi Türkiyat Araştırmaları Enstitüsü Dergisi, 23, $145-150$.

Uzmen, S, \& Mağden, D. (2002). Okulöncesi eğitim kurumlarına devam eden alt yaş çocuklarının prososyal davranışlarının resimli çocuk kitapları ile desteklenmesi. M.Ü. Atatürk Eğitim Fakültesi Eğitim Bilimleri Dergisi. 15, 193-212

Yıldırım, A. \& Şimşek, H. (2016). Sosyal bilimlerde nitel araştırma yöntemleri. Ankara: Seçkin yayınları. 